\title{
URGENSI PENGATURAN STATUS BADAN HUKUM PDAM TIRTA PAKUAN KOTA BOGOR MENJADI PERUSAHAAN UMUM DAERAH (PERUMDA)
}

\author{
Teguh Setiadi \\ PDAM Tirta Pakuan Kota Bogor \\ Jalan Siliwangi No. 121 Bogor \\ T39uhroxx@yahoo.com \\ Naskah diterima : 10/02/2019, revisi : 14/06/2018, disetujui 17/06/2019
}

\begin{abstract}
ABSTRAK
Perkembangan globalisasi menuntut berbagai badan usaha, baik milik pemerintah/daerah maupun swasta, saling berkompetisi. Di dalam kontens demikian, maka kompetisi dilakukan secara sehat dengan memperhatikan aturan dan tata kelola yang baik. Selama ini, pemerintah baik pusat maupun daerah memiliki wewenang membentuk badan usaha yang berbadan hukum. Syaratnya secara konstitusional memenuhi semangat ketentuan Pasal 33 UUD 1945 di mana pembentukan badan usaha berbadan hukum dimaksud ditujukan untuk sebesar-besarnya kemakmuran masyarakat. Salah satu badan usaha berbadan hukum di daerah yang didirikan pemerintah daerah adalah Badan Usaha Milik Daerah (BUMD). Pada saat ini, BUMD diatur melalui UU Nomor 23 Tahun 2014 tentang Pemerintah Daerah. Undang-Undang Nomor 23 Tahun 2014 tentang Pemerintahan Daerah (UU Pemda) tersebut melakukan perubahan nomenklatur dan pengatur status badan hukum dibandingkan ketentuan sebelumnya pada Badan Usaha Milik Daerah atau lazim disingkat BUMD. Sebagai turunan dari ketentuan UU Pemda yang mengatur BUMD, maka pada 27 Desember 2017 terbit Peraturan Pemerintah Nomor 54 Tahun 2017 tentang Badan Usaha Milik Daerah (BUMD) dan Peraturan Menteri Dalam Negeri Nomor 37 Tahun 2018 tentang Pengangkatan dan Pemberhentian Anggota Dewan Pengawas atau Anggota Komisaris dan Anggota Direksi Badan Usaha Milik Daerah (BUMD).
\end{abstract}

Kata kunci : Pengaturan, badan hukum, perusahaan umum daerah. 


\section{A. Latar Belakang}

Timbulnya badan usaha milik negara di Indonesia berangkat dari ketentuan konstitusional Pasal 33 UUD 1945 yang menghendaki cabang cabang produksi yang penting bagi negara dan menguasai hajat hidup orang banyak dikuasai oleh negara. Menurut konsep Mohammad Hatta, Pasal 33 UUD 1945 merupakan sendi utama bagi politik ekonomi dan politik sosial Indonesia. Ujungnya adalah keselarasan demokrasi politik yang dilengkapi demokrasi ekonomi, karena tanpa demokrasi ekonomi maka akan terjadi konsentrasi kekuatan ekonomi pada satu atau beberapa kelompok yang kemudian akan membentukkan kekuasaan ekonomi yang dapat "membeli " atau "mengatur" kekuasaan politik. ${ }^{1}$ Konsepsi demikian mendorong negara berperan lebih aktif dengan membentuk badan usaha milik negara sebagai salah satu pelaku ekonomi dalam perekonomian nasional berdasarkan demokrasi ekonomi untuk mewujudkan kesejahteraan seluruh masyarakat. Secara operasional, konsep di atas dijabarkan di dalam UU Nomor 19 Tahun 2003 tentang Badan Usaha Milik Negara (BUMN). Di daerah, dibentuk pula Badan Usaha Milik Daerah (BUMD) yang selaras dengan di pusat, sebagai salah satu pelaku ekonomi.

Di dalam implementasinya, BUMD memiliki berbagai tantangan dan permasalahan. Pertama, permasalahan efisiensi. Secara umum, seringkali terjadi BUMD tidak efisien, mengalami pemborosan dana karena pengelolanya tidak memiliki keahlian cukup. Keputusan terkait investasi baru seringkali dilakukan tidak profesional. Kedua, masalah intervensi dan birokrasi. Tidak dapat disangkal banyak BUMD kalah bersaing dengan sektor wasta salah satunya adalah besarnya campur tangan dan lambannya pemerintah daerah dalam mengantisipasi perubahan situasi dan kondisi bisnis. Kadang keputusan diberikan berlarut-larut sehingga tidak dapat kompetitif dengan swasta. Ketiga, pengendalian dan 
pengawasan. Di dalam BUMD, pemerintah daerah membentuk badan pengawas yang terkadang tidak memiliki latar belakang bisnis sama sekali. Hal ini menyebabkan pengawasan tidak profesional sehingga berdampak pada kesehatan BUMD. ${ }^{2}$

Di dalam perspektif hukum, dalam rangka meningkatkan kualitas layanan, maka diperlukan organisasi profesional, berintegritas dan kompetitif sehingga dengan terbitnya UU Nomor 23 Tahun 2014 tentang Pemerintahan Daerah di atas, membuka peluang untuk ditinjau dan disesuaikan status badan hukum yang semula Perusahaan Daerah untuk konteks PDAM Tirta Pakuan Kota Bogor menjadi Perusahaan Umum Daerah sehingga diharapkan akan berdampak pada peningkatan mutu layanan serta profesionalitas dari BUMD yang bergerak di bidang penyediaan air minum. Selain itu, melalui perubahan status badan hukum diharapkan permasalahan yang selama ini dihadapi BUMD pada umumnya dapat diminimalisasi seperti lemahnya efisiensi, independensi dan pengawasan sehingga dapat menjadi korporasi profesional yang kompetitif.

\section{B. Tinjauan Filosofis dan Sosiologis Pengaturan Status Badan Hukum} Perusahaan Umum Daerah Air Minum Tirta Pakuan Kota Bogor Menjadi Perusahaan Umum Daerah (Perumda).

Secara filosofis di dalam pengaturan badan hukum Perusahaan Umum Daerah Air Minum Tirta Pakuan Kota Bogor, berangkat dari pemahaman bahwa refleksi filosofis senantiasa berupaya untuk menangkap makna hakiki dari hukum guna mencapai ketertiban, kepastian dan keadilan. ${ }^{3}$ Dengan demikian, refleksi filosofis akan menuju pada pengungkapan hakikat dengan menemukan landasan terdalam dari keberadaan hukum sejauh yang mampu dijangkau akal budi manusia.

\footnotetext{
hlm.8-11.

${ }^{2}$ Lihat, Wawan Zulmawan, Kenapa Harus BUMD, Jakarta: Jala Permata Aksara, 2015,

${ }^{3}$ Theo Huijbers, Filsafat Hukum, Yogyakarta : Kanisius, 1995, hlm.18.
} 
Setidaknya dapat merespon dua hal yang fundamental yakni: pertama, apa yang menjadi landasan kekuatan mengikat dari hukum dan kedua, atas dasar kriteria apa hukum dapat dinilai keadilannya. ${ }^{4}$

Pembukaan Undang-Undang Dasar Negara Republik Indonesia (UUD NRI) Tahun 1945 memuat cita filosofis Pancasila dan tujuan dari pembangunan nasional, salah satunya, yakni memajukan kesejahteraan umum.

Notonagoro berpendapat bahwa nilai-nilai cita filosofis Pancasila tergolong nilai-nilai kerokhanian, tetapi nilai-nilai kerokhanian yang mengakui adanya nilai material dan nilai vital. Nilainilai Pancasila yang tergolong nilai kerokhanian itu juga mengandung nilai-nilai lain secara lengkap dan harmonis, baik nilai material, nilai vital, nilai kebenaran, nilai keindahan atau nilai estetis, nilai kebaikan atas nilai moral, maupun nilai kesucian yang sistematis-hierarkhis, yang dimulai dari sila Ketuhanan Yang Maha Esa sebagai 'dasar' sampai dengan sila Keadilan Sosial bagi seluruh rakyat Indonesia sebagai 'tujuan'. ${ }^{5}$ Dengan demikian, cita filosofis Pancasila harus dapat menjadi bintang pemandu (leitern) perilaku kehidupan berbangsa dan bernegara serta menjadi dasar pembentukan kaidah hukum.

Refleksi ketentuan di atas di dalam sistem negara kesatuan yang terbagi atas penyelenggaraan pemerintah di pusat dan di daerah direalisasikan dalam desentralisasi kekuasaan untuk mencerminkan demokratisasi di daerah. Desentralisasi kekuasaan (kewenangan) tersebut sebagaimana termaktub pada Pasal 18 ayat (1) UUD 1945 bahwa Negara Kesatuan Republik Indonesia di bagi atas daerah-daerah provinsi dan daerah provinsi itu di bagi atas kabupaten dan kota yang

\footnotetext{
${ }^{4}$ Bernard Arief Sidharta, Refleksi tentang Struktur Ilmu Hukum, Bandung : Mandar Maju, 1999, hlm.119.

${ }^{5}$ Kaelan dan Achmad Zubaidi, Pendidikan Kewarganegaraan Untuk Perguruan Tinggi, (Yogyakarta: Paradigma, 2007), hal. 22.
} 
diatur dengan undang-undang. Undang-undang dimaksud adalah UU Nomor 23 Tahun 2014 tentang Pemerintahan Daerah.

Pada hakikatnya desentralisasi dan otonomi daerah ditujukan dan selalu berorientasi pada kesejahteraan masyarakat. Salah satu wujudnya melalui pemberian wewenang atributif di dalam UU Nomor 23 Tahun 2014 tentang Pemerintahan Daerah di mana pemerintah daerah dapat memiliki Badan Usaha Milik Daerah yang pembentukan, penggabungan, pelepasakan kepemilikan dan/atau pembubarannya ditetapkan dengan Peraturan Daerah yang berpedoman pada peraturan perundang-undangan. Salah satu perusahaan daerah dimaksud adalah Perusahaan Daerah Air Minum Tirta Pakuan Kota Bogor yang hendak diubah status badan hukumnya menjadi perusahaan umum daerah dengan memperhatikan peraturan perundang-undangan terkait.

Penyelenggaraan Perusahaan Daerah Air Minum sedari awal dimaksudkan untuk memberikan pelayanan air minum kepada masyarakat baik melalui perpipaan dan/atau melalui sarana lainnya. Pelayanan air minum merupakan kebutuhan pokok masyarakat yang menjadi tanggung jawab pemerinah untuk pengadaannya. Penyelenggaraan perusahaan daerah air minum merupakan cerminan layanan publik yang harus diberikan optimal pada masyarakat dengan memperhatikan prinsip good governance. Buruknya kualitas pelayanan publik tercermin pada derajat implementasi good governance. Bila tidak ada perbaikan maka mempengaruhi indeks kepuasaan dan kepercayaan masyarakat terhadap kinerja perusahaan oleh karena itu, perusahaan daerah air minum dituntut profesional di dalam menyelenggarakan layanannya. Apabila layanan air semakin berkualitas, maka berkontribusi besar pada konsepsi negara kesejahteraan yang dianut oleh Pembukaan UUD 1945.

Secara sosiologis, hukum dipandang sebagai lembaga kemasyarakatan yaitu himpunan daripada kaedah-kaedah dari segala 
tingkatan yang berkisar pada suatu kebutuhan pokok di dalam kehidupan masyarakat. Hukum menjadi pedoman bagaimana bertingkah laku, sebagai alat untuk menjaga keutuhan masyarakat dan sebagai suatu sistem pengendalian sosial. ${ }^{6}$ Dengan demikian, secara sosiologis akan diuji apakah hukum dan peraturan perundang-undangan berfungsi di dalam masyarakat dan mampu merespon kebutuhan masyarakat. ${ }^{7}$

Di dalam perspektif sosiologis, kebijakan desentralisasi senantiasa memiliki dua tujuan utama yakni tujuan politik dan tujuan administrasi. Pertama, tujuan politik senantiasa diarahkan untuk memberi ruang gerak kepada masyarakat dalam tataran pengembangan partisipasi, akuntabilitas, transparansi dan demokrasi. Di sisi lain, dari aspek pendemokrasian daerah, hal itu memposisikan pemerintah daerah sebagai media pendidikan politik bagi masyarakat di tingkat lokal. Dengan demikian, diharapkan pada saatnya secara agregat daerah akan memberikan kontribusi signifikan terhadap perkembangan pendidikan politik secara nasional dan terwujudnya masyarakat sipil. Kedua, tujuan administrasi yaitu memposisikan pemerintah daerah sebagai unit pelayanan yang dekat dengan masyarakat. Dengan demikian, pemerintah daerah wajib berfungsi maksimal dan optimal menyediakan layanan publik berkualitas (termasuk di dalamnya penyediaan air minum) secara efektif, efisien dan ekonomis untuk meningkatkan kesejahteraan masyarakat lokal.

Berangkat dari tujuan politik dan administrasi di atas maka menjadi jelas misi utama dari pemerintah daerah adalah memajukan kesejahteraan warga dan masyarakatnya melalui pemenuhan kebutuhan dasar antara lain berupa air minum.

Di dalam perspektif otonomi daerah, tidak dapat dilepaskan tujuan otonomi daerah dalam membuka sekat

\footnotetext{
${ }^{6}$ Soerjono Soekanto, Beberapa Permasalahan Hukum Dalam Kerangka Pembangunan Di Indonesia, Jakarta : Yayasan Penerbitan Universitas Indonesia, 1976, hlm5.

${ }^{7}$ Soerjono Soekanto, Mengenal Sosiologi Hukum, Bandung : Alumni, 1982, hlm.18.
} 
komunikasi, transparansi, akuntabilitas dan persamaan hak masyarakat di dalam proses penyelenggaraan pemerintahan daerah. Konsekuensinya, otonomi daerah memberikan ruang dan kesempatan luas pada publik untuk berpartisipasi dalam proses penyelenggaraan pemerintahan daerah. Selain itu, masyarakat diarahkan dan didik untuk semakin memahami hak-haknya sehingga terbentuk komunitas kritis di dalam menyampaikan aspirasi dan kontrol publik bagi penyelenggaraan pemerintahan daerah. Pada akhirnya, implikasi otonomi daerah diharapkan dapat membentuk proses pemberdayaan masyarakat (empowering) dan pemberian pendidikan politik masyarakat (demokrasi) yang lebih optimal.

Secara sosiologis, hukum dipandang sebagai lembaga kemasyarakatan yaitu himpunan daripada kaedah-kaedah dari segala tingkatan yang berkisar pada suatu kebutuhan pokok di dalam kehidupan masyarakat. Hukum menjadi pedoman bagaimana bertingkah laku, sebagai alat untuk menjaga keutuhan masyarakat dan sebagai suatu sistem pengendalian sosial. Dengan demikian, secara sosiologis akan diuji apakah hukum dan peraturan perundangundangan berfungsi di dalam masyarakat dan mampu merespon kebutuhan masyarakat.

Di dalam perspektif sosiologis, kebijakan desentralisasi senantiasa memiliki dua tujuan utama yakni tujuan politik dan tujuan administrasi. Pertama, tujuan politik senantiasa diarahkan untuk memberi ruang gerak kepada masyarakat dalam tataran pengembangan partisipasi, akuntabilitas, transparansi dan demokrasi. Di sisi lain, dari aspek pendemokrasian daerah, hal itu memposisikan pemerintah daerah sebagai media pendidikan politik bagi masyarakat di tingkat lokal. Dengan demikian, diharapkan pada saatnya secara agregat daerah akan memberikan kontribusi signifikan terhadap 
perkembangan pendidikan politik secara nasional dan terwujudnya masyarakat sipil. Kedua, tujuan administrasi yaitu memposisikan pemerintah daerah sebagai unit pelayanan yang dekat dengan masyarakat. Dengan demikian, pemerintah daerah wajib berfungsi maksimal dan optimal menyediakan layanan publik berkualitas (termasuk di dalamnya penyediaan air minum) secara efektif, efisien dan ekonomis untuk meningkatkan kesejahteraan masyarakat lokal.

Berangkat dari tujuan politik dan administrasi di atas maka menjadi jelas misi utama dari pemerintah daerah adalah memajukan kesejahteraan warga dan masyarakatnya melalui pemenuhan kebutuhan dasar antara lain berupa air minum. Di dalam perspektif otonomi daerah, tidak dapat dilepaskan tujuan otonomi daerah dalam membuka sekat komunikasi, transparansi, akuntabilitas dan persamaan hak masyarakat di dalam proses penyelenggaraan pemerintahan daerah. Konsekuensinya, otonomi daerah memberikan ruang dan kesempatan luas pada publik untuk berpartisipasi dalam proses penyelenggaraan pemerintahan daerah.

Selain itu, masyarakat diarahkan dan didik untuk semakin memahami hak-haknya sehingga terbentuk komunitas kritis di dalam menyampaikan aspirasi dan kontrol publik bagi penyelenggaraan pemerintahan daerah. Pada akhirnya, implikasi otonomi daerah diharapkan dapat membentuk proses pemberdayaan masyarakat (empowering) dan pemberian pendidikan politik masyarakat (demokrasi) yang lebih optimal.

C. Urgensi Pengaturan Status Badan Hukum Perusahaan Umum Daerah Air Minum Tirta Pakuan Kota Bogor Menjadi Perusahaan Umum Daerah (Perumda) Pasca Berlakunya UU No. 23 Tahun 2014 Tentang Pemerintahan Daerah 
Terbitnya UU Nomor 23 Tahun 2014 tentang Pemerintahan Daerah yang mengkodifikasi BUMD ke dalam dua jenis yaitu Perusahaan Umum Daerah dan Perseroan Daerah merupakan bentuk penguatan dimensi legal terhadap pengaturan dan pengakuan BUMD secara lebih komperhensif. Kemudian terbit PP Nomor 54 Tahun 2017 tentang BUMD. Namun, persoalanya, khusus perusahaan air minum lebih teknis diatur oleh Permendagriyang hingga saat naskah ini dibuat belum terbit. Dengan demikian hal tersebut mendorong diperlukan kajian yang cermat agar (i) tidak terjadi disharmonisasi pada pembentukan perda di daerah sebagai dasar bagi BUMD dan (ii) implikasi pilihan bentuk hukum BUMD dapat direspon secara memadai dan komperhensif.

Di dalam hasil penelaahan awal, selama ini, pembentukan Badan Usaha Milik Daerah (BUMD) sebagai usaha yang dimiliki pemerintah daerah memiliki tujuan yang jelas yaitu sebagai salah satu sumber penerimaan daerah (PAD). Namun demikian, di dalam dinamikanya, senantiasa mengalami berbagai tantangan. Pertama, masih terdapat BUMD yang lebih banyak mendapat suntikan dana dari pemerintah daerah daripada keuntungan yang didapat sehingga menjadi beban APBD. Kedua, dari segi aspek hukum, BUMD tidak seperti BUMN yang mendapat payung hukum spesifik pada UU Nomor 19 Tahun 2003, masih didasarkan pada perda dan UU Nomor 5 Tahun 1962 tentang Perusahaan Daerah. Permendagri Nomor 3 Tahun 1998 menegaskan bahwa bentuk BUMD dapat berupa perusahaan daerah atau perseroan. Ketiga, status keuangan pada BUMD. Apakah masih berstatus keuangan daerah atau sudah menjadi keuangan badan usaha? Hal ini akan berdampak pada keluwesan pengambilan kebijakan.

PDAM Tirta Pakuan Kota Bogor sendiri memiliki payung hukum berinduk pada Perda Nomor 16 Tahun 2011 tentang Perusahaan Daerah Air Minum (PDAM) Tirta Pakuan Kota Bogor. Maksud dan 
tujuan pendirian PDAM tersebut dinyatakan pada Pasal 4 yaitu memenuhi kebutuhan air minum masyarakat dengan mengutamakan pemerataan pelayanan dan persyaratan kesehatan serta pelestarian lingkungan. Sedangkan tujuannya untuk meningkatkan derajat kesehatan dan produktivitas masyarakat serta mendorong pertumbuhan ekonomi daerah dan sebagai salah satu sumber PAD.

Merujuk ketentuan Pasal 4 Perda Nomor 16 Tahun 2011 di atas maka nampak jelas unsur public service mendominasi maksud dan tujuan pendirian PDAM Tirta Pakuan Kota Bogor. Meski demikian tidak menutup dorongan profit karena menjadi salah satu sumber PAD. Dengan demikian, perlu penelaahan lanjutan apabila hendak dilakukan reposisi status badan hukum, maka kompatibilitas karakter dan kebutuhan PDAM dengan pilihan badan hukumnya perlu diselaraskan. Apalagi dalam kurun waktu terakhir ini (2016-2017), PDAM Tirta Pakuan Kota Bogor berdasarkan indikator kinerja kehandalan produk dan layanan jasa berdasarkan survey yang dilakukan Universitas Ibn Khaldun Bogor, telah memenuhi harapan responden pengguna air PDAM.

Capaian demikian tentu harus dilembagakan dalam bentuk badan hukum yang mampu merawat capaian bahkan meningkatkannya lebih baik. Dalam konteks teoritik di atas, maka kajian pilihan badan hukum perlu didukung upaya mendorong karakter produk hukum agar berkonsep hukum responsif di mana hukum dimaksud menjadi sarana respon atas kebutuhan-kebutuhan dan aspirasi masyarakat, termasuk dalam hal ini kebutuhan kelembagaan dari PDAM itu sendiri.

Pada hakikatnya, Perusahaan Daerah Air Minum (PDAM) a dalah badan usaha milik pemerintah daerah, yang melaksanakan fungsi pelayanan menghasilkan kebutuhan air minum/air bersih bagi masyarakat, diharapkan dapat memberikan pelayanan akan air bersih yang merata kepada seluruh lapisan masyarakat, membantu 
perkembangan bagi dunia usaha dan menetapkan struktur tarif yang disesuaikan dengan tingkat kemampuan masyarakat. Artinya PDAM memiliki dua fungsi, yaitu fungsi pelayanan kepada masyarakat dan fungsi menambah penerimaan daerah.

Dalam hal ini keberadaan PDAM sebagai BUMD dapat membantu memenuhi kebutuhan masyarakat, menunjang bagi perkembangan kelangsungan dunia usaha dan perkembangan ekonomi di daerah, percepatan pembangunan di daerah, karena air bersih yang dihasilkan PDAM merupakan barang yang essensial yang menyangkut hajat hidup orang banyak.

Di sisi lain dengan menjual air bersih ini PDAM diharapkan juga memiliki efisiensi sehingga memiliki kemampuan dalam memupuk dana dan menghasilkan keuntungan, yang juga merupakan kontribusi bagi PAD. Dana dari PAD ini yang kemudian diharapkan mampu menunjang terselenggaranya rencana pembangunan di daerah, dan hasil pembangunan itu pada akhirnya dapat dinikmati kembali oleh masyarakat. Maka sejalan dengan itu agar PDAM berjalan dengan tujuan dan fungsinya, memerlukan pengelolaan yang baik dan benar dengan memperhatikan segala kekuatan, kelemahan, peluang dan ancaman yang dimilikinya, dalam upayanya makin mensejahterakan masyarakat di era otonomi ini.

Perusahaan Daerah Air Minum merupakan salah satu Badan Usaha Milik Daerah (BUMD) yang bergerak di bidang penyediaan air bersih untuk kebutuhan masyarakat. Keberadaan Perusahaan Daerah Air Minum sebagai unsur pelayanan publik, harus mengutamakan aspek sosial. Hal ini tercermin di dalam penetapan harga produk lebih mempertimbangkan kemampuan masyarakat, namun di balik fungsinya sebagai unsur pelayanan publik juga tidak terlepas dari dimensi ekonomi, yaitu mencari keuntungan, karena menjadi salah satu sumber Pendapatan Asli Daerah. 
Perusahaan Daerah Air Minum mempunyai fungsi pokok pelayanan umum kepada masyarakat, sehingga di dalam menjalankan fungsinya tersebutPerusahaan Daerah Air Minum harus mampu membiayai dirinya sendiri dan harus berusaha mengembangkan tingkat pelayanan dan diharapkan mampu memberikan sumbangan kepada Pemerintah Daerah dalam fungsinya sebagai sumber Pendapatan Asli Daerah. Oleh karena itu perlu penyelenggaraan dan pembinaan PDAM yang didasarkan pada asas ekonomi yang sehat, sehingga mampu berkompetisi dengan perusahaan lain dalam meraih peluang bisnis yang lebih menguntungkan.

Pemerintah Daerah mendirikan perusahaan daerah atas dasar pertimbangan: menjalankan ideologi yang dianutnya bahwa sarana produksi milik masyarakat; melindungi konsumen dalam hal ada monopoli alami; dalam rangka mengambil alih perusahaan asing; menciptakan lapangan kerja atau mendorong pembangunan ekonomi daerah; dianggap cara yang efisien untuk menyediakan layanan masyarakat, dan/atau menebus biaya, serta menghasilkan penerimaan untuk Pemerintah Daerah.

PDAM Tirta Pakuan Pakuan Kota Bogor mempunyai fungsi pokok sebagai penyedia air minum bagi masyarakat dan sebagai salah satu sumber pendapatan asli daerah. PDAM Tirta Pakuan Pakuan Kota Bogor bertujuan memenuhi kebutuhan air bersih bagi masyarakat sesuai dengan standar mutu dan kesehatan. Untuk memenuhi kebutuhan masyarakat tersebut PDAM Tirta Pakuan Pakuan Kota Bogorberusaha meningkatkan kapasitas produksi dengan melakukan investasi berupa pengadaan sarana dan prasarana air bersih yang dapat memproduksi air sehingga secara bertahap kebutuhan masyarakat baik dari segi kuantitas maupun kualitas dapat terpenuhi 
Pendirian PDAM sebagai salah satu perusahaan daerah telah diatur pada tahun 1962 oleh Undang-Undang Republik Indonesia Nomor 5 Tahun 1962 tentang Perusahaan Daerah, dimana sampai sekarang Undang-Undang ini belum dicabut. Undang-Undang ini dibentuk bertujuan untuk membantu terlaksananya program umum Pemerintah di bidang ekonomi dalam rangka melaksanakan Pasal 33 Undang-Undang Dasar Negara Republik Indonesia Tahun 1945.

Dalam undang-undang tersebut, yang dimaksud dengan perusahaan daerah adalah semua perusahaan yang didirikan berdasarkan undang-undang ini yang modalnya untuk seluruhnya atau untuk sebagian merupakan kekayaan daerah yang dipisahkan, kecuali jika ditentukan lain dengan atau berdasarkan undang-undang. Adapun pendirian perusahaan daerah tersebut didirikan dengan peraturan daerah atas kuasa dari Undang-Undang Republik Indonesia Nomor 5 Tahun 1962 tentang Perusahaan Daerah tersebut.

PDAM sebagai BUMD yang dibentuk oleh pemerintah kota, selain sebagai perusahaan pelayanan publik, walaupun merupakan perusahaan yang modalnya bersumber dari kekayaan negara yang dipisahkan, namun PDAM bukan semata-mata perusahaan yang berorientasi pada keuntungan atau profit oriented, namun PDAM juga perusahaan yang melaksanakan pelayanan untuk kepentingan umum.

Hal tersebut diatur dalam Pasal 5 ayat (1) Undang-Undang Republik Indonesia Nomor 5 Tahun 1962 tentang Perusahaan Daerah yang menyebutkan bahwa perusahaan daerah adalah suatu kesatuan produksi yang bersifat:

a. memberi jasa;

b. menyelenggarakan kemanfaatan umum;

c. memupuk pendapatan.

Sifat perusahaan daerah tersebut juga diatur dalam Pasal 2 huruf a Peraturan Menteri Dalam Negeri Nomor 1 Tahun 1984 tentang Tata 
Cara Pembinaan dan Pengawasan Perusahaan Daerah Di Lingkungan Pemerintah Daerah yang berpedoman pada Undang-Undang Republik Indonesia Nomor 5 Tahun 1962 tentang Perusahaan Daerah yang menyebutkan bahwa sifat usaha dari perusahaan daerah terutama adalah perusahaan berusaha di bidang penyediaan pelayanan bagi kemanfaatan umum disamping mendapatkan keuntungan.

Adapun tujuan dari perusahaan daerah adalah untuk turut serta melaksanakan pembangunan daerah khususnya dan pembangunan ekonomi nasional umumnya dalam rangka ekonomi terpimpin untuk memenuhi kebutuhan rakyat dengan mengutamakan industrialisasi dan ketentraman serta kesenangan kerja dalam perusahaan, menuju masyarakat yang adil dan makmur.

Dalam Peraturan Menteri Dalam Negeri Nomor 1 Tahun 1984 tentang Tata Cara Pembinaan dan Pengawasan Perusahaan Daerah Di Lingkungan Pemerintah Daerah disebutkan bahwa tujuan dari perusahaan daerah adalah sebagai salah satu sumber pendapatan asli daerah dan sebagai sarana pengembangan perekenomian dalam rangka pembangunan daerah.

PDAM sebagai salah satu perusahaan daerah, tidak terlepas dari unsur pembinaan dan pengawasan dari pemerintah. Pembinaan adalah kegiatan untuk memberikan pedoman bagi perusahaan daerah dalam perencanaan, pelaksanaan dan pengendalian dengan maksud agar perusahaan daerah yang bersangkutan dapat melaksanakan tugas dan fungsinya secara berdaya gunadan berhasil guna serta dapat berkembang dengan baik. Pengawasan adalah seluruh proses kegiatan penilaian terhadap perusahaan daerah dengan tujuan agar perusahaan daerah tersebut melaksanakan fungsinya dengan baik dan berhasil mencapai tujuan yang telah ditetapkan.

Pengawasan kepada direksi perusahaan daerah berada di bawah Kepala Daerah/pemegang saham/saham prioritet atau badan yang 
ditunjuknya. Pembinaan umum terhadap perusahaan daerah dilakukan oleh Menteri Dalam Negeri dan pengawasan umum terhadap perusahaan daerah dilakukan oleh Menteri Dalam Negeri dan Kepala Daerah. Sedangkan untuk pembinaan terhadap perusahaan daerah dilakukan oleh Kepala Daerah. Kepala Daerah sebagai pemilik perusahaan daerah melakukan penguasaan terhadap perusahaan daerah yang berhubungan dengan hak, wewenang dan kekuasaan pemerintah daerah.

Oleh karena itu, PDAM sebagai perusahaan daerah, dalam pelaksanaan kegiatan dan pengelolaannya tunduk pada peraturan yang ditetapkan oleh Menteri Dalam Negeri dan ketentuan yang ditetapkan oleh Kepala Daerah. Di Kota Bogor, telah memiliki perusahaan daerah air minum yang diberikan kewenangan oleh pemerintah daerahnya untuk menyelenggarakan pelayanan air minum yaitu Perusahaan Daerah Air Minum (PDAM) Tirta Pakuan Kota Bogor.

Dengan didirikannya PDAM Tirta Pakuan Kota Bogor sebagai penyelenggara pelayanan air minum di Kota Bogor yang dibentuk oleh Pemerintah Kota Bogor, maka untuk saat ini, PDAM merupakan badan usaha yang menyelenggarakan pelayanan air minum di wilayah yang menjadi kewenangannya yaitu di wilayah Kota Bogor.

Sebelum adanya Undang-Undang Republik Indonesia Nomor 7 Tahun 2004 tentang Sumber Daya Air, pengelolaan usaha PDAM untuk menyelenggarakan pelayanan air minum tidak diatur secara terinci dan melalui peraturan-peraturan yang terpisah-pisah.

Dengan adanya Undang-Undang Republik Indonesia Nomor 7 Tahun 2004 tentang Sumber Daya Air yang kemudian ditindaklanjuti dengan Peraturan Pemerintah Republik Indonesia Nomor 16 Tahun 2005 tentang Sistem Penyediaan Air Minum, maka PDAM memiliki tugas dan wewenang yang jelas dalam menyelenggarakan pelayanan air minum untuk memenuhi kebutuhan dasar manusia yaitu air bersih. 
Dari ketentuan mengenai tugas dan tanggung jawab PDAM sebagai BUMD penyelenggara pelayanan air minum yang diatur dalam Peraturan Pemerintah Republik Indonesia Nomor 16 Tahun 2005 tentang Pengembangan Sistem Penyediaan Air Minum, khususnya tanggung jawab PDAM untuk melaksanakan penyelenggaraan pelayanan air minum dengan prinsip tata pengusahaan yang baik, maka untuk sebagai standar atau pedoman dalam penyelenggaraan pelayanan air minumnya, PDAM Tirta Pakuan Kota Bogor berpedoman pada peraturan perundang-undangan yang ditetapkan oleh Pemerintah Daerah yang mengacu pada peraturan perundangundangan yang lebih tinggi.

Sebagai pedoman mendasar dalam pelaksanaan tugas dan tanggung jawabnya, PDAM Tirta Pakuan Kota Bogor memiliki Peraturan Daerah Kota Bogor Nomor 16 Tahun 2011 tentang Perusahaan Daerah Air Minum Tirta Pakuan Kota Bogor, dimana dalam Pasal 4 Perda tersebut menyebutkan maksud dan tujuan didirikannya PDAM Tirta Pakuan Kota Bogor adalah sebagai berikut:

1) PDAM didirikan dengan maksud untuk memenuhi kebutuhan air minum masyarakat dengan mengutamakan pemerataan pelayanan dan persyaratan kesehatan serta pelestarian lingkungan

2) PDAm didirikan dengan tujuan untuk meningkatkan derajat kesehatan dan produktivitas masyarakat serta mendorong perekonomian daerah dan sebagai salah satu sumber PAD

Adapun bidang usaha PDAM Tirta Pakuan Kota Bogor di dalam Pasal 5 menyebutkan :

1) Bidang Usaha PDAM adalah menyelenggarakan SPA untuk kebutuhan masyarakat dan usaha lainnya dalam bidang pemyediaan air minum 
2) SPAM sebagaimana dimaksud pada ayat (1) dapat dilakukan melalui sistem jaringan perpipaan dan/atau bukan melalui jaringan perpipaan

3) SPAM dengan jaringan perpipaan sebagaimana dimaksud pada ayat (2) meliputi unit air baku, unit produksi, unit distribusi, unit pelayanan, dan unit pengelolaan

4) SPAM bukan melalui jaringan pepipaan sebagaimana dimaksud pada ayat (2) di ataranya terminal air, mobil tangki air dan bentuk lainnya yang memugkinkan.

Dari tugas dan tanggung jawab yang telah diatur dalam Peraturan Daerah tersebut, perlu ditunjang dengan pengelolaan dan manajemen di internal PDAM Tirta Pakuan Kota Bogor. Untuk menciptakan tata kelola perusahaan yang baik, PDAM Tirta Pakuan Kota Bogor berpedoman pada Peraturan Menteri Dalam Negeri Nomor 2 Tahun 2007 tentang Organ dan Kepegawaian Pada Perusahaan Daerah Air Minum.

Dalam Peraturan Menteri Dalam Negeri tersebut diatur mengenai pedoman pengangkatan Dewan Pengawas dan Direksi, wewenang dan tanggung jawab Dewan Pengawas dalam melakukan pengawasan pengelolaan PDAM, wewenang dan tanggung jawab Direksi dalam mengelola PDAM dan kepegawaian.

Untuk melaksanakan ketentuan yang diatur dalam Peraturan Menteri Dalam Negeri tersebut, Walikota Bogor menetapkan Peraturan Walikota Nomor 41 Tahun 2016 tentang Organ dan Kepegawaian PDAM Tirta Pakuan Kota Bogor, dimana untuk menciptakan tata kelola perusahaan yang baik, ditetapkan organ PDAM Tirta Pakuan Kota Bogor yaitu:

a. Walikota sebagai pemilik PDAM;

b. Dewan Pengawas;

c. Direksi. 
Untuk melaksanakan kegiatan secara terintegrasi demi mencapai tujuan dan target perusahaan, maka organisasi adalah sebuah wadah atau tempat dimana setiap peserta bersedia menyumbangkan tenaga, melakukan kegiatan yang terpadu demi tercapainya tujuan yang telah ditentukan.

Adanya pembagian kerja serta penugasan kerja yang jelas diantara para pelaksananya, sesuai dengan prinsip-prinsip organisasi karena struktur organisasi yang efisien merupakan dasar yang sangat penting bagi keberhasilan mencapai tujuan. Sebuah organisasi yang baik, para peserta organisasinya dipilah-pilah berdasarkan tugas, wewenang dan tanggung jawab masing-masing dan perlu adanya pembinaan dan pengarahan terhadap personil organisasi tersebut agar sikap bawahannya selaras dengan tujuan organisasi.

Berdasarkan Peraturan Menteri Dalam Negeri Nomor 1 Tahun 1984 tentang Tata Cara Pembinaan dan Pengawasan Perusahaan Daerah DiLingkungan Pemerintah Daerah menyebutkan bahwa Kepala Daerah menetapkan struktur organisasi perusahaan daerah.

Oleh karena itu, struktur organisasi PDAM Tirta Pakuan Kota Bogor ditetapkan dalam Peraturan Walikota Bogor Nomor 25 Tahun 2013 tentang Struktur Organisasi dan Tata Kerja PDAM Tirta Pakuan Kota Bogor dan uraian tugas serta kewenangan masing-masing organisasi diatur dalam Peraturan Direksi PDAM Tirta Pakuan Kota Bogor Nomor 41 Tahun 2016 tentang Organ dan Kepegawaian PDAM Tirta Pakuan Kota Bogor.

Saat ini, BUMD diatur pada UU Nomor 23 Tahun 2014 tentang Pemerintah Daerah. Undang-Undang Nomor 23 Tahun 2014 tentang Pemerintahan Daerah (UU Pemda) tersebut melakukan perubahan nomenklatur dan pengatur status badan hukum dibandingkan ketentuan sebelumnya pada Badan Usaha Milik Daerah atau lazim disingkat BUMD. Pasal 1 angka 40 UU Pemda menegaskan, Badan Usaha 
Milik Daerah atau BUMD adalah "badan usaha yang seluruh atau sebagian besar modalnya dimiliki daerah". Pasal 331 ayat (3) UU Pemda mengatur bahwa BUMD dapat berbadan hukum (a) perusahaan umum daerah dan (b) perusahaan perseroan daerah. Adapun alasan pembentukannya diatur pada Pasal 331 ayat (5) UU Pemda yaitu bisa didasarkan (a) kebutuhan daerah dan (b) kelayakan bidang usaha BUMD yang akan dibentuk. Sumber modalnya pada Pasal 332 dan Pasal 333 UU Pemda diatur yaitu bisa penyertaan modal daerah, pinjaman, hibah dan modal lainnya. Bila penyertaan modal daerah maka harus ditetapkan dengan Perda.

Sebagai turunan dari ketentuan UU Pemda yang mengatur BUMD, maka pada 27 Desember 2017 terbit Peraturan Pemerintah Nomor 54 Tahun 2017 tentang Badan Usaha Milik Daerah (BUMD) (selanjutnya disingkat PP BUMD). Pada konsiderans menimbang dari PP tersebut ditegaskan bahwa PP BUMD diterbitkan dalam rangka melaksanakan Pasal 331 ayat (6), Pasal 335 ayat (2), Pasal 336 ayat (5), Pasal 337 ayat (2), Pasal 338 ayat (4), Pasal 340 ayat (2), Pasal 342 ayat (3) dan Pasal 343 ayat (2) UU Nomor 23 Tahun 2014 tentang Pemerintahan Daerah. Ketentuan di atas berlaku untuk semua BUMD, termasuk dalam hal ini Perusahaan Daerah Air Minum (PDAM) Tirta Pakuan Kota Bogor.

Selain pengaturan di dalam PP BUMD, terbit Peraturan Menteri Dalam Negeri (Permendagri) Nomor 37 Tahun 2018 tentang Pengangkatan dan Pemberhentian Anggota Dewan Pengawas atau Anggota Komisaris dan Anggota Direksi Badan Usaha Milik Daerah (BUMD) sebagai pelaksanaan Pasal 39 dan Pasal 58 PP BUMD. Di dalam Permendagri No.57 Tahun 2018 diatur proses pemilihan anggota Dewan Pengawas atau Komisaris dan anggota Direksi dilakukan melalui seleksi. Demikian pula diatur pengangkatan dan pemberhentian anggota Dewan Pengawas atau anggota Komisaris dan anggota Direksi sebagai bentuk perwujudan tata kelola perusahaan 
yang baik. Selanjutnya dalam ketentuan Permendagri No.57 Tahun 2018 mengatur terperinci hal-hal menyangkut mekanisme seleksi di maksud di atas termasuk syarat dan mekanisme seleksi menyangkut anggota Dewan Pengawas, Komisaris dan Direksi.

\section{Penutup}

Pada hakikatnya, Badan Usaha Milik Daerah (BUMD) memiliki peran strategis bagi daerah mengingat fungsi gandanya yaitu salah satu sarana bagi penerimaan keuangan daerah (PAD) dan memberikan layanan publik di daerah sesuai jenis usahanya. Secara konseptual, Badan Usaha Milik Daerah (BUMD) adalah badan usaha yang seluruh atau sebagian besar modalnya dimiliki oleh daerah. Dengan otonomi daerah dalam upaya peningkatan ekonomi, dapat dibentuk BUMD sendiri baik untuk tujuan publik service, profit oriented atau kombinasi keduanya

Penyusunan Rancangan Peraturan Daerah Kota Bogor tentang Perusahaan Umum Daerah Air Minum Tirta Pakuan Kota Bogor wajib mempertimbangkan landasan filosofis, sosiologis dan yuridis sehingga ketika diberlakukan dapat merespon kebutuhan masyarakat, meningkatkan layanan mutu bagi konsumen atau pelanggan dan sekaligus menciptakan kesejahteraan di masyarakat lokal.

Dalam Penyusunan Rancangan Peraturan Daerah Kota Bogor tentang Perusahaan Umum Daerah Air Minum Tirta Pakuan Kota Bogor berangkat dari kebutuhan harmonisasi dan sinkronisasi hukum serta diharapkan berdampak pada mutu layanan perusahaan. Sebab pasca terbitnya Undang-Undang Nomor 23 Tahun 2014 tentang Pemerintahan Daerah (UU Pemda) dan PP Nomor 54 Tahun 2017 tentang Badan Usaha Milik Daerah (BUMD) maka nomenklatur BUMD mendapat perumusan dan pengaturan pada pasal-pasalnya. Pasal 1 angka 40 UU Pemda menegaskan, Badan Usaha Milik Daerah atau BUMD adalah "badan usaha yang seluruh atau sebagian besar modalnya dimiliki daerah". Pasal 331 
ayat (3) UU Pemda mengatur bahwa BUMD dapat berbadan hukum (a) Perusahaan Umum Daerah dan (b) Perusahaan Perseroan Daerah. Adapun alasan pembentukannya diatur pada Pasal 331 ayat (5) UU Pemda yaitu bisa didasarkan (a) kebutuhan daerah dan (b) kelayakan bidang usaha BUMD yang akan dibentuk. Sumber modalnya pada Pasal 332 dan Pasal 333 UU Pemda diatur yaitu bisa penyertaan modal daerah, pinjaman, hibah dan modal lainnya. Bila penyertaan modal daerah maka harus ditetapkan dengan Perda.

Berkaitan dengan hal resebut di atas, maka perlu segera diterbitkan Peraturan Daerah Kota Bogor tentang Perusahaan Umum Daerah Air Minum Tirta Pakuan Kota Bogor sebagai landasan yuridis peningkatan kualitas layanan dari perusahaan air minum di Kota Bogor serta penguatan status badan hukum yang selaras dengan UU Nomor 23 Tahun 2014 tentang Pemerintahan Daerah dan PP Nomor 54 Tahun 2017 tentang Badan Usaha Milik Daerah (BUMD) serta Peraturan Menteri Dalam Negeri (Permendagri) Nomor 37 Tahun 2018 tentang Pengangkatan dan Pemberhentian Anggota Dewan Pengawas atau Anggota Komisaris dan Anggota Direksi Badan Usaha Milik Daerah (BUMD). 


\section{DAFTAR PUSTAKA}

A.V Dicey, Introduction To The Study Of The Law Of The Constitution, Fifth edition, London,

Barry M Mitnick, The Political Economy of Regulation: Creating, Designing, and Removing Regulatory Forms, Columbia University Press New York, 1980, page: 5-6.

Bernard Arief Sidharta, Refleksi tentang Struktur Ilmu Hukum, Bandung: Mandar Maju, 1999.

Dhimas Tetuko Kusumo, "Kajian Yuridis Bentuk Badan Usaha Milik Daerah Di Bidang Perbankan Pasca Berlakunya Undang-Undang Nomor 23 Tahun 2014 tetang Pemerintahan Daerah", Privat Law Vol IV Nomor 1 JanuariJuni 2016, hlm.22.

Elizabeth Zoller,Introduction to Public Law, Mattinus Nijhoff Publishers, Netherland, 2008.

Elli Ruslina, Dasar Perekonomian Indonesia Dalam Penyimpangan Mandat Konstitusi UUD Negara Tahun 1945, Jakarta: Total Media,2013.

Kaelan dan Achmad Zubaidi, Pendidikan Kewarganegaraan Untuk Perguruan Tinggi, Yogyakarta: Paradigma, 2007.

Moh. Mahfud MD, Demokrasi dan Konstitusi di Indonesia, Liberty, Jogjakarta, 1993.

Mulyana W Kusumah dan Paul S Baut, Hukum, Politik dan Perubahan Sosial, Jakarta: YLBHI, 1988.

Nandang Kusnadi dan R Muhammad Mihradi, Eksekusi Putusan Pengadilan Tata Usaha Negara, Bogor: UNPAK Press, 2017.

Peter Mahmud Marzuki, Penelitian Hukum, Jakarta: Kencana, 2005.

Soerjono Soekanto dan Sri Mamudji, Penelitian Hukum Normatif: Suatu Tinjauan Singkat, Jakarta: Rajawali Pers, 2003.

PH. Collin, Dictionary of Law, Fourth Edition, Bloomsbury Publishing Plc, London. 2004 
Philipus M Hadjon, Pengantar Hukum Administrasi Indonesia, Yogyakarta: Gadjah Mada University Press, 2015.

R Muhammad Mihradi, Kebebasan Informasi Publik versus Rahasia Negara, Bogor: Ghalia Indonesia, 2011.

Ridwan HR, Hukum Administrasi Negara, Jakarta: Rajagrafindo Persada, 2006.

Ronny Sautma Hotma Bako, "Permasalahan Hukum Atas Bentuk Badan Hukum Pada Badan Usaha Milik Daerah", Kajian Volume 15, No.4 Desember 2010.

SF Marbun sebagaimana dikutip oleh R. Muhammad Mihradi, "Neo Liberalisme, Negara Hukum dan Hukum Administrasi", Jurnal Hukum Academia, Fakultas Hukum Universitas Pakuan, 2004, hlm.23.

Soerjono Soekanto, Beberapa Permasalahan Hukum Dalam Kerangka Pembangunan Di Indonesia, Jakarta : Yayasan Penerbitan Universitas Indonesia, 1976.

Soerjono Soekanto, Mengenal Sosiologi Hukum, Bandung : Alumni, 1982.

Suparto Wijoyo, Karakteristik Hukum Acara Peradilan Administrasi, Surabaya: Airlangga University Press, 1997.

Survey Universitas Ibn Khaldun Bogor dalam http://www.metropolitan.id/2017/06/kinerja-dan-layanan-pdamtirta-pakuan-dinilai-baik/

Theo Huijbers, Filsafat Hukum, Yogyakarta : Kanisius, 1995.

Wawan Zulmawan, Kenapa Harus BUMD, Jakarta: Jala Permata Aksara, 2015. 